\title{
Complex Technology of Sewage Purification from Heavy-Metal lons by Natural Adsorbents and Utilization of Sewage Sludge
}

\author{
Iryna Zasidko ${ }^{1 *}$, Myroslava Polutrenko², Oleg Mandryk², Yuliia Stakhmych², \\ Nataliia Petroshchuk ${ }^{3}$ \\ 1 State Agency of Water Resources of Ukraine, 23A Akademika Sakharova str., Ivano-Frankivsk, 76014, Ukraine \\ 2 Ivano-Frankivsk National Technical University of Oil and Gas, 15 Karpatska str., Ivano-Frankivsk, \\ 76019, Ukraine \\ 3 Borys Grinchenko Kyiv University, 18/2 Bulvarno-Kudriavska str., Kyiv, 04053, Ukraine \\ * Corresponding author's e-mail: zasidkoiryna@gmail.com
}

\begin{abstract}
The aspects of complex technology of sewage purification and utilization of purification sludge were investigated in the article. The authors substantiated the possibility of purifying sewage from heavy-metal ions by means of zeolite and utilizing sewage sludge in bricks production. The adsorption capacity of the zeolite from Sokyrnytsia deposit was studied for cupric and manganese ions in relation to its fractional composition. The comparative effectiveness studies of heavy metals adsorption by natural zeolite and anthracite were carried out. The optimal sorption parameters of these ions were selected based on the investigation results of their adsorption dynamics in the $\mathrm{Cu}^{2+}$ and $\mathrm{Mn}^{2+}$ solutions. The prospects of sewage sludge utilization by means of its thermal pyrolysis at the temperatures of $600-700^{\circ} \mathrm{C}$ were studied. The modifying additive was obtained, which can be added to the ceramic mixture and increase the porosity, reduce the density and decrease the thermal conductivity of course solid bricks.
\end{abstract}

Keywords: heavy-metal ions; adsorption; thermal pyrolysis, modifying additive, ceramic mixture.

\section{INTRODUCTION}

Sewage purification is connected with the formation of different types of solid wastes - the products of reagent purification, waste activated sludge or waste adsorbents. The reutilization of reagent purification products as mineral fertilizers is a prospective method (Tulaydan et al. 2017), but for this purpose this strategy is limited in use to pollutants, i.e. plant food elements (nitrogen, phosphorus, and some microelements).

The accumulation of waste activated sludge from biological wastewater treatment technologies is an important environmental issue- mainly in the case of realizing the traditional technologies (Malovanyy et al., 2016), and to a lesser extent, in the case of realizing the innovative technologies of biological wastewater treatment - OLAND (De Clippeleir et al., 2011), SHARON (Van
Kempen et al., 2005), ANAMMOX (Malovanyy et al., 2014), and others.

The wastewater purification technologies from ammonium (Malyovanyy et al., 2013) and heavy metals (Melnyk et al., 2015) result in the accumulation of waste adsorbents. As ammoniasaturated adsorbents can be used as slow-release fertilizers, utilization methods should be studied for heavy-metal saturated waste adsorbents. Thus, the accumulation of sewage sludge (SS) is an extremely important environmental issue. Its amount increases every year and in Ukraine it equals than 5 billion tons total. More than 10 thousand hectares of land have been withdrawn from economic turnover to store such a large amount of sludge. The absence of SS utilization process causes the expropriation of land for sludge storage sites and their territory is constantly increasing (Ministry of Ecology 
and Natural Resources of Ukraine et al. 2016, Ministry of Ecology and Natural Resources of Ukraine et al. 2017).

Besides, the existing sludge drying sites often do not have any waterproofing and are the sources of groundwater and air pollution. The groundwater contamination by heavy metals, which, as a result of inefficient sewage treatment, are present in SS composition and are toxic pollutants with cumulative effects is extremely dangerous. SSs create the danger of horizontal and vertical migration of heavy metals in the environment. Therefore, it is important to purify the wastewater from heavy-metal ions and remove them from the "sludge-soilplants" system (Mandryk et al. 2016, Adamenko et al. 2016). It is topical to search for new methods of SS utilization, which, according to the possibility of their further use, are in the group of waste, which can be used as secondary raw materials.

In the processes of sewage purification from heavy-metal ions, special place is held by sorbents, such as activated carbon, silica gels and clays, which, can provide high adsorption capacity at a relatively low cost. It is especially topical to study natural adsorbents, one of which is zeolite. The major characteristics of zeolite are its cation-exchange properties and high capacity, its specific surface area, determined by water, is $59 \mathrm{~m}^{2} / \mathrm{g}$ (Scott et al. 2003, Gregg, et al. 1984, Vasylenko et al. 1999). Literary sources state that SSs are usually utilized as soil fertilizers, as feed additives and in road construction. SSs can be also utilized as fillers in asphalt concrete, in base course and in cement production (Breus, et al. 2007, Bień, et al. 2007, Girol, et al. 2006). However, recent research studies, related to the problems of SS accumulation and utilization, demonstrate the prospects of their use in brick production. At present, the ash and slag from thermal power plants, metallurgical slag, wastes from mining industry, coal preparation plants and sludge from aeration plants are added to the batch mixture used for brick manufacturing (Abdrakhimov, et al. 2012).

The purpose of the article is to study the possibility of using natural zeolite from the Sokyrnytsia deposit in purifying the wastewater emitted by utility companies, from cupric and manganese ions and of SS utilization in brick manufacturing.

\section{MATERIALS AND METHODS}

The zeolite of natural fraction with grain sizes from $0.125 \mathrm{~mm}$ to $1 \mathrm{~mm}$ was used in the experiment. The fractional composition of natural zeolite, used in the experimental studies, was defined by sifting it through the openings with the diameter of $1 \mathrm{~mm}, 0.5 \mathrm{~mm}$ and $0.125 \mathrm{~mm}$. Four fractions were obtained: fraction 1 (with grain diameter less than $0.125 \mathrm{~mm}$ ) made up $36.2 \%$ of the total zeolite mass; fraction 2 (with grain diameter ranging from $0.125 \mathrm{~mm}$ to $0.5 \mathrm{~mm}$ ) was the basis of zeolite and made up $57.2 \%$ of the total zeolite mass; fraction 3 (with grain diameter ranging from $0.5 \mathrm{~mm}$ to $1 \mathrm{~mm}$ ) made up $4.5 \%$ of the total zeolite mass; fraction 4 (with grain diameter more than $1 \mathrm{~mm}$ ) made up $2.1 \%$ of the total zeolite mass. The diagram of zeolite distribution by fractions is shown in Figure 1.

The zeolite adsorption capacity was defined on the solutions of cupric nitrate and manganese nitrate with the concentrations of $0.05 \mathrm{mg} / \mathrm{dm}^{3}$, $0.1 \mathrm{mg} / \mathrm{dm}^{3}, 1 \mathrm{mg} / \mathrm{dm}^{3}, 5 \mathrm{mg} / \mathrm{dm}^{3}$ and $10 \mathrm{mg} / \mathrm{dm}^{3}$, prepared from standard samples.

The zeolite adsorption capacity was studied in the following way: $1 \mathrm{~g}$ of adsorbent and $250 \mathrm{~cm}^{3}$ of the solutions of cupric nitrate and manganese nitrate of different concentrations were put into conical flasks. The resulting solutions were mixed and left undisturbed. These operations were repeated every twelve hours. Forty-eight hours after the beginning of the experiment, the solutions were filtered through the ashless (blue ribbon) filter and the residual concentration of ions was measured by the photometric method on KFK-3-01 device (Tables 1, 2, 3). The experiment temperature was $(20 \pm 1)^{\circ} \mathrm{C}$.

The rate of ion adsorption (S, \%) was defined by the following formula:

$$
S=\frac{C_{0}-C_{i}}{C_{0}} \times 100 \%
$$

where: $C_{0}$ - initial concentration of the studied ion in the solution, $\mathrm{mg} / \mathrm{dm}^{3}$;

$C_{i}$ - residual concentration of the studied ion in the solution, $\mathrm{mg} / \mathrm{dm}^{3}$.

In order to determine the possibility of SS utilization in brick production, the sludges, before being added to the ceramic mixture, underwent the pretreatment by means of deliquification, grinding and then pyrolysis - calcination in vacuum at the temperatures of $600-700^{\circ} \mathrm{C}$. In this 


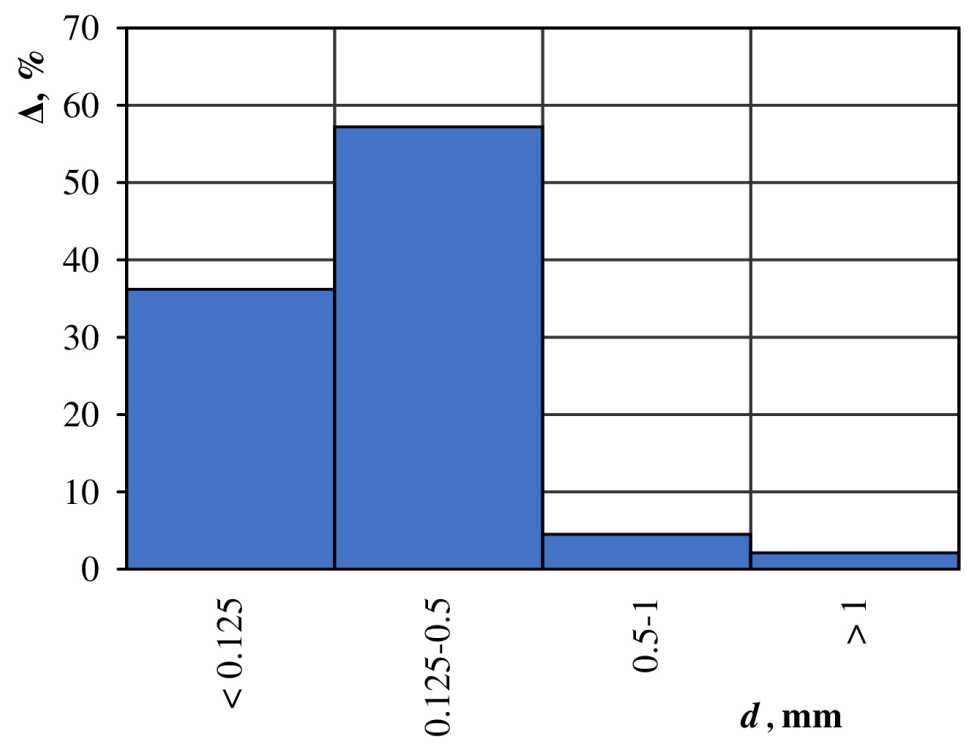

Fig. 1. Diagram of zeolite distribution by fractions ( $\Delta$ - specific fraction content)

case, SSs were converted into flammable gas, and metal oxides remained in the gasifying chamber and could be used as mineral fillers.

Three types of batches from moderate-plastic yellow clay, medium-plastic grey clay and argillite were used as raw materials:

- batch No. 1: yellow and grey clays at the ratio of $65 \%$ and $35 \%$;

- batch No. 2: yellow and grey clays at the ratio of $30 \%$ and $70 \%$;

- batch No. 3: yellow and grey clays at the ratio of $65 \%, 35 \%$ and argillite.

The raw material was crushed, mixed and dampened to reach the molding water content. The modifying additive, obtained as a result of SS thermal pyrolysis at the temperatures of $600-700^{\circ} \mathrm{C}$, was added to the mixture. For the batch No. 1 the amount of modifying additive was $1 \%-6 \%$ and $10 \%$ of the sample mass. For the batch No. $2-3 \%, 5 \%, 10 \%, 15 \%, 20 \%$ and $30 \%$ of the sample mass. For the batch No. $3-1 \%-5 \%$ of the sample mass. The laboratory samples were formed in metal moulds with the dimensions of $50 \times 50 \times 15 \mathrm{~mm}$ by means of a wooden hammer. The SS percentage was designated on the formed samples, which were left for air drying for 5 days and burned afterwards. The laboratory samples were burned in the electric furnace at the temperature of $950^{\circ} \mathrm{C}$ in the following mode:

- rise from $20^{\circ} \mathrm{C}$ to the maximum temperature at the rate of $120^{\circ} \mathrm{C} /$ hour $-7.5-8$ hours;

- holding at final temperature -2 hours.
After burning, the water adsorption of laboratory samples was determined and they were also tested for density, porosity, thermal conductivity and strength.

\section{RESULTS AND DISCUSSION}

The results of the studies on determining the zeolite adsorption capacity depending on its fractional composition within 48 hours are shown in Table 1.

The experimental studies showed that the cupric and manganese ions were most efficiently adsorbed by the zeolite fraction with the grain diameter from 0.125 to $0.5 \mathrm{~mm}$ and it was used in further research. It was found out that at low concentrations $\left(0.05-0.1 \mathrm{mg} / \mathrm{dm}^{3}\right)$ zeolite completely adsorbed the cupric and manganese ions within 48 hours, regardless of the sorbent grain diameter. The adsorption efficiency decreased as the concentration of ions increased in the solution. For the cupric ions with the concentration of $1.0 \mathrm{mg} /$ $\mathrm{dm}^{3}$, the adsorption rate was $97.5 \%$, with the concentration of $5.0 \mathrm{mg} / \mathrm{dm}^{3}-49.2 \%$, and with the concentration of $10.0 \mathrm{mg} / \mathrm{dm}^{3}-27.6 \%$, respectively. The experiments showed different results for the manganese ions. In particular, for the manganese ions with the concentration of $1.0 \mathrm{mg} / \mathrm{dm}^{3}$ the adsorption rate was $59.0 \%$, with the concentration of $5.0 \mathrm{mg} / \mathrm{dm}^{3}-28.4 \%$, and with the concentration of $10.0 \mathrm{mg} / \mathrm{dm}^{3}-16.2 \%$, respectively. 
Table 1. Zeolite adsorption capacity for cupric and manganese ions depending on zeolite grain diameter

\begin{tabular}{|c|c|c|c|c|c|c|c|c|c|}
\hline \multirow[b]{3}{*}{ No. } & \multirow{3}{*}{$\begin{array}{l}\text { Concentration of } \mathrm{Cu}^{2+} \\
\text { and } \mathrm{Mn}^{2+} \text { ions in the } \\
\text { initial solution, } \mathrm{mg} / \mathrm{dm}^{3}\end{array}$} & \multicolumn{8}{|c|}{ Residual concentration of ions in the solution, $\mathrm{mg} / \mathrm{dm}^{3}$} \\
\hline & & $\mathrm{Cu}^{2+}$ & $\mathrm{Mn}^{2+}$ & $\mathrm{Cu}^{2+}$ & $\mathrm{Mn}^{2+}$ & $\mathrm{Cu}^{2+}$ & $\mathrm{Mn}^{2+}$ & $\mathrm{Cu}^{2+}$ & $\mathrm{Mn}^{2+}$ \\
\hline & & \multicolumn{2}{|c|}{$\begin{array}{l}\text { initial fraction, } \\
0.125-1 \mathrm{~mm}\end{array}$} & \multicolumn{2}{|c|}{$\begin{array}{c}\text { zeolite grain } \\
\text { diameter of } \\
0.125-0.5 \mathrm{~mm}\end{array}$} & \multicolumn{2}{|c|}{$\begin{array}{l}\text { zeolite grain } \\
\text { diameter } \\
0.5-1 \mathrm{~mm} \\
\end{array}$} & \multicolumn{2}{|c|}{$\begin{array}{c}\text { grain diameter over } \\
1 \mathrm{~mm}\end{array}$} \\
\hline 1 & 0.05 & 0 & 0 & 0 & 0 & 0 & 0 & 0 & 0 \\
\hline 2 & 0.1 & 0 & 0 & 0 & 0 & 0 & 0 & 0 & 0 \\
\hline 3 & 1 & 0.093 & 0.56 & 0.025 & 0.41 & 0.22 & 0.71 & 0.36 & 0.79 \\
\hline 4 & 5 & 2.69 & 3.70 & 2.54 & 3.58 & 2.73 & 3.79 & 2.91 & 3.88 \\
\hline 5 & 10 & 7.37 & 8.54 & 7.24 & 8.38 & 7.42 & 8.63 & 7.59 & 8.75 \\
\hline
\end{tabular}

The comparative analysis of the data, provided in Table 1, indicates that the tested zeolite shows higher adsorption selectivity to the cupric ions. This proves the rule that the sorption of heavy-metal ions increases with the growth of atomic weight and increase of ion radius. The atomic weight of the cupric ions is $63.546 \mathrm{amu}$ and the ion radius is $72 \mathrm{pm}$, the atomic weight of manganese ions is $54.93855 \mathrm{amu}$ and the ion radius is $80 \mathrm{pm}$, that is, the cupric ions have a greater atomic weight and smaller radius and, therefore, they are more easily absorbed by zeolite (Nekrasov et al. 1973).

The adsorption dynamics of $\mathrm{Cu}^{2+} \mathrm{Ta} \mathrm{Mn}^{2+}$ ions from the solutions with the concentration of $1 \mathrm{mg} / \mathrm{dm}^{3}$ was analyzed by the authors of the article and is shown in Table 2.

The obtained results showed that zeolite demonstrated different sorption properties in relation to the cupric and manganese ions. In particular, the most active $\mathrm{Cu}^{2+}$ adsorption was observed during the first hour when zeolite adsorbed $69.0 \%$ of $\mathrm{Cu}^{2+}$ ions. Later, the sorption speed decreased. However, almost complete sorption of the $\mathrm{Cu}^{2+}$ ions $(97.5 \%)$ was achieved after 48 hours. The adsorption of the manganese ions was slightly slower. During the first three hours, only $1.0-2.0 \%$ of $\mathrm{Mn}^{2+}$ were adsorbed, in three hours the adsorption

Table 2. Zeolite adsorption dynamics of cupric and manganese ions from the solutions with the concentration of $1 \mathrm{mg} / \mathrm{dm}^{3}$

\begin{tabular}{|c|c|c|c|}
\hline \multirow{2}{*}{$\begin{array}{c}\text { Experiment } \\
\text { No. }\end{array}$} & $\begin{array}{c}\text { Adsorption time } \\
\text { of } \mathrm{Cu}^{2+} \text { and } \\
\mathrm{Mn}^{2+} \text { ions, } \mathrm{hr}\end{array}$ & \multicolumn{2}{|c|}{$\begin{array}{c}\text { Residual concentration of } \\
\text { ions, } \mathrm{mg} / \mathrm{dm}^{3}\end{array}$} \\
\cline { 3 - 4 } & 1 & 0.310 & 0.990 \\
\hline 1 & 1 & 0.290 & 0.990 \\
\hline 2 & 2 & 0.275 & 0.980 \\
\hline 3 & 4 & 0.260 & 0.802 \\
\hline 4 & 6 & 0.200 & 0.650 \\
\hline 5 & 24 & 0.025 & 0.410 \\
\hline 6 & 48 & & \\
\hline
\end{tabular}

rate was $19.8 \%$, and in 48 hours only $59.0 \%$ of $\mathrm{Mn}^{2+}$ ions were adsorbed. The calculation results of the adsorption rate of cupric and manganese ions with the initial concentration of $1.0 \mathrm{mg} / \mathrm{dm}^{3}$ are shown in Figure 2.

The study was carried out to compare the adsorption capacity of zeolite with the adsorption capacity of anthracite. The experiments on the cupric and manganese ions were performed with the use of $1 \mathrm{~g}$ of adsorbents, fractions with grain diameter of $0.125-0.5 \mathrm{~mm}$ and within 48 hours. The research results on the adsorption capacity of zeolite are given in Table 1, and of anthracite in Table 3.

The data analysis in Tables 1 and 3 shows that anthracite does not adsorb the cupric and manganese ions completely, even from the solutions with low concentrations. This is proven by the results of comparing the adsorption rate of zeolite and anthracite for cupric and manganese ions (Table 4).

At low concentrations of copper and manganese of $0.05-0.1 \mathrm{mg} / \mathrm{dm}^{3}$ the adsorption rate of anthracite for these pollutants after 48 hours was in the range of $64-53 \%$.

With an increase in the initial concentration of ions in the solution, the sorption efficiency decreases. Thus, with the initial concentration of the cupric and manganese ions of $1.0 \mathrm{mg} / \mathrm{dm}^{3}$, after 48 hours, the concentration of contaminations decreased by $63 \%$ and $50 \%$, and with an initial concentration of ions of $5.0 \mathrm{mg} / \mathrm{dm}^{3}$, it decreased by $40.4 \%$ and $26 \%$, respectively.

Figures 3-4 show the dependencies of adsorption rates of zeolite and anthracite for the cupric and manganese ions.

It can be seen from the dependencies above that at low initial concentrations of heavy metals $\left(0.05-0.1 \mathrm{mg} / \mathrm{dm}^{3}\right)$ the adsorption rate of zeolite for the $\mathrm{Cu}^{2+}$ and $\mathrm{Mn}^{2+}$ ions is $100 \%$, of anthracite - only (60-64\%) for the $\mathrm{Cu}^{2+}$ ions and (53-56\%) 


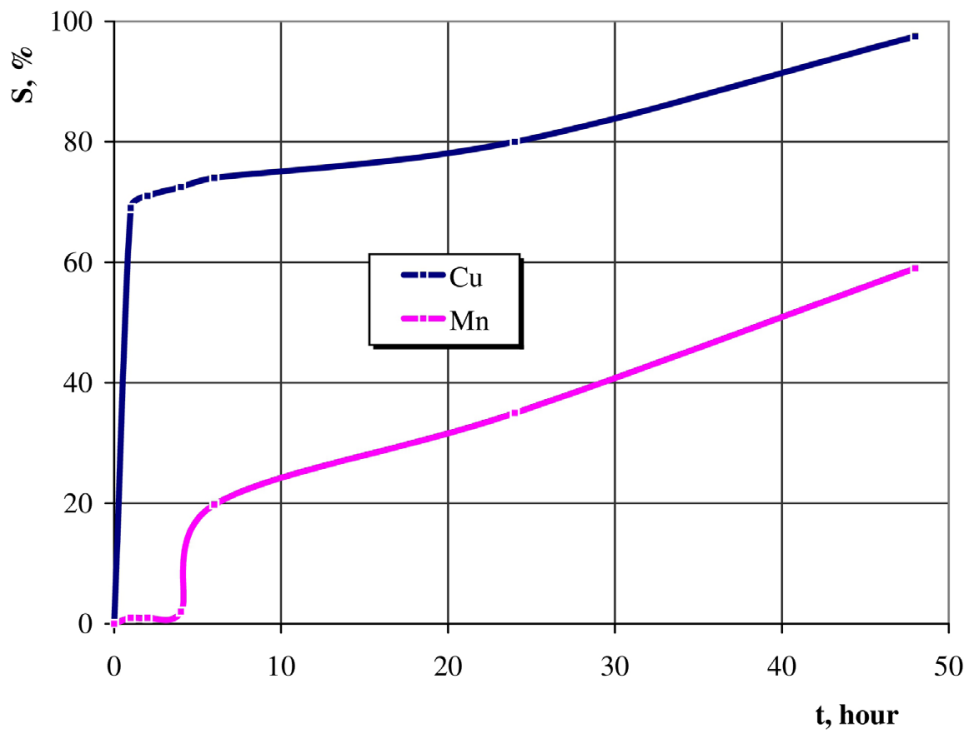

Fig. 2. Time dependence of the adsorption rate of the cupric and manganese ions for the initial cupric and manganese concentration in the solution of $1.0 \mathrm{mg} / \mathrm{dm}^{3}$

for the $\mathrm{Mn}^{2+}$ ions. For the initial concentration of heavy-metal ions of $1.0-10.0 \mathrm{mg} / \mathrm{dm}^{3}$, the adsorption rate of zeolite for the ions is $1.5-1.2$ times higher for the cupric ions and 1.2-1.1 times higher for the manganese ions.

The given data show that it is much more prospective to use natural zeolite for the adsorption of heavy-metal ions. That is why, natural zeolite was further studied from the perspective of SS utilization. The potential for using SS in the production of ceramic materials was studied both for face bricks and for course solid bricks. These bricks are becoming increasingly popular nowadays. They have no internal cavities inside and are used for the erection of foundations, bearing walls and partitions. As these bricks are hidden behind a decorative layer, the DSTU requirements for their appearance are minimal: the face surface may be rough, coarse, heterogeneous in

Table 3. Anthracite adsorption for cupric and manganese ions

\begin{tabular}{|c|c|c|c|}
\hline \multirow{2}{*}{ No. } & \multirow{2}{*}{$\begin{array}{c}\text { Concentration } \\
\text { of } \mathrm{Cu}^{2+} \text { and } \mathrm{Mn}^{2+} \\
\text { ions in the initial } \\
\text { solution, } \mathrm{mg} / \mathrm{dm}^{3}\end{array}$} & $\begin{array}{c}\text { Residual concentration of ions in } \\
\text { the solution, } \mathrm{mg} / \mathrm{dm}^{3}\end{array}$ \\
\cline { 3 - 4 } & 0.05 & \multicolumn{2}{|c|}{ Anthracite adsorption } \\
\hline 1 & 0.018 & $\mathrm{Cu}^{2+}$ & 0.022 \\
\hline 2 & 0.1 & 0.040 & 0.047 \\
\hline 3 & 1.0 & 0.37 & 0.50 \\
\hline 4 & 5.0 & 2.98 & 3.70 \\
\hline 5 & 10.0 & 7.67 & 8.66 \\
\hline
\end{tabular}

colour, curved edges and sides may be observed. After baking, the brick samples were analyzed for appearance, physical and mechanical properties. Visible SS inclusions were detected on the surface of samples. This means that the ceramic mixture is not suitable for manufacturing face bricks and may be used for producing course solid bricks, if other indicators meet the requirements of regulatory documents.

In the process of defining the physical and mechanical parameters, water adsorption of samples was defined first of all (Table 5) and the samples with water adsorption of up to $13 \%$ were selected for further research.

The data in Table 5 show that the moisture content in the samples from batches No. 2 and No. 3 is high and such compositions cannot be used to produce bricks, as this will reduce their frost resistance. That is why, the samples made from batch No. 1 were selected for further research. The laboratory samples with the water adsorption of $11 \%-13 \%$, were analyzed for porosity and density.

It was found that the porosity of samples grew with the increased content of modifying additive, and their density consequently fell, with the compressive strength corresponding to grade M 125 (Table 6).

The analysis of physical and mechanical properties of the laboratory samples from Table 6 indicates that the most effective is the introduction of SS modifying additive in the amount of 
Table 4. The adsorption rate of zeolite and anthracite for the cupric and manganese ions

\begin{tabular}{|c|c|c|c|c|c|}
\hline \multirow{2}{*}{ No. } & \multirow{2}{*}{$\begin{array}{c}\text { Concentration of } \mathrm{Cu}^{2+} \text { and } \\
\mathrm{Mn}^{2+} \text { ions in the initial solution, } \\
\mathrm{mg} / \mathrm{dm}^{3}\end{array}$} & \multicolumn{4}{|c|}{ Adsorption rate, $\mathrm{S}, \%$} \\
\cline { 3 - 6 } & & \multicolumn{2}{|c|}{ Zeolite adsorption } & \multicolumn{2}{|c|}{ Anthracite adsorption } \\
\cline { 3 - 6 } & 0.05 & 100 & 100 & $\mathrm{Cu}^{2+}$ & 54 \\
\hline 1 & 0.1 & 100 & 100 & 60 & 53 \\
\hline 2 & 1.0 & 97.5 & 59 & 63 & 50 \\
\hline 3 & 5.0 & 49.2 & 28.4 & 40.4 & 26 \\
\hline 4 & 10.0 & 27.6 & 16.2 & 23.3 & 13.4 \\
\hline 5 & & &
\end{tabular}

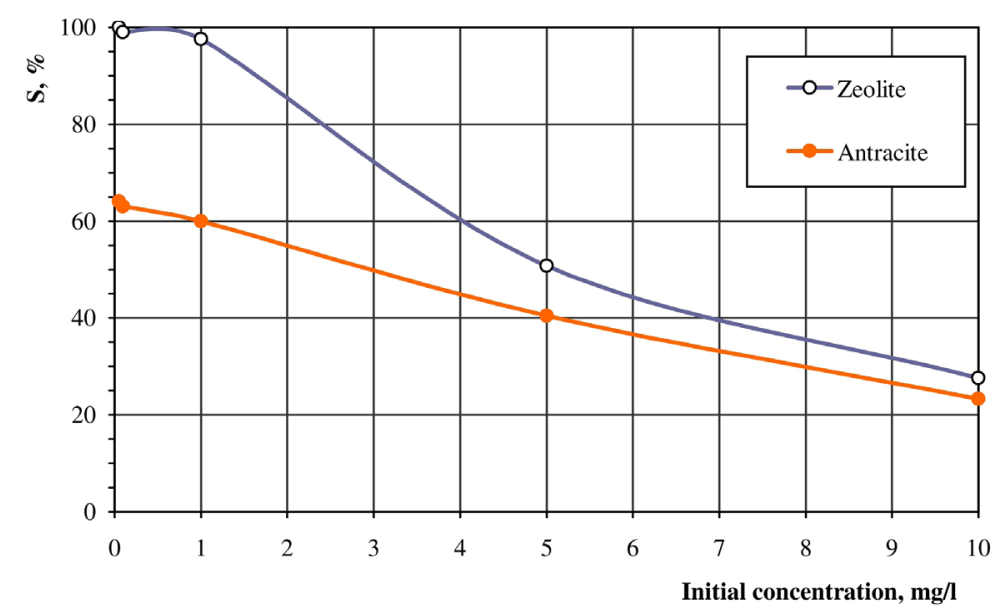

Fig. 3. Dependence of the adsorption rate of zeolite and anthracite for the cupric ions on the initial concentration of contaminations in the solution

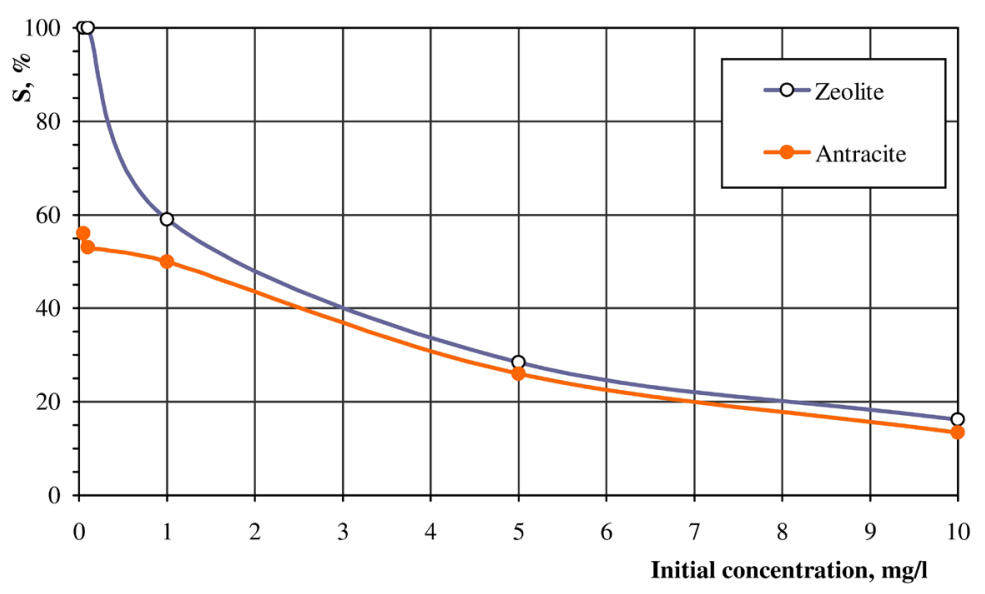

Fig. 4. Dependence of the adsorption rate of zeolite and anthracite for the manganese ions on the initial concentration of contaminations in the solution

$5.0 \%$ of brick mass. With such an amount of additive, the porosity of bricks is the greatest, the density is the lowest and the compressive strength of bricks corresponds to grade M 125.

The comparative studies of physical and mechanical properties of the laboratory samples with the modifying additive in the amount of $5.0 \%$ of brick mass were compared with the properties of bricks, manufactured according to the process regulations of the Ivano-Frankivsk enterprise OJSC "Budivelni Materialy".

In addition to porosity, density and strength, the thermal conductivity of samples was determined. It is a very important characteristic of bricks, which depends on the brick density and falls with the decrease in brick density (Table 7). 
Table 5. Water adsorption of laboratory samples

\begin{tabular}{|c|c|c|c|c|c|}
\hline \multirow{2}{*}{ No. } & \multicolumn{3}{|c|}{ Composition of batch No. 1} & \multirow[b]{2}{*}{ SS, \% } & \multirow{2}{*}{$\mathrm{W}, \%$} \\
\hline & Yellow clay, \% & Grey clay, \% & Argillite, $\%$ & & \\
\hline 1 & 65 & 35 & --- & 1 & 11.0 \\
\hline 2 & 65 & 35 & --- & 2 & 11.2 \\
\hline 3 & 65 & 35 & --- & 3 & 11.6 \\
\hline 4 & 65 & 35 & --- & 4 & 12.3 \\
\hline 5 & 65 & 35 & --- & 5 & 13.0 \\
\hline 6 & 65 & 35 & --- & 6 & 15.8 \\
\hline \multirow[t]{2}{*}{7} & 65 & 35 & --- & 10 & 16.6 \\
\hline & \multicolumn{3}{|c|}{ Composition of batch No. 2} & & \\
\hline No. & Yellow clay, \% & Grey clay, \% & Argillite, $\%$ & SS, \% & W, \% \\
\hline 1 & 30 & 70 & --- & 3 & 15.9 \\
\hline 2 & 30 & 70 & --- & 5 & 16.6 \\
\hline 3 & 30 & 70 & --- & 10 & 21.7 \\
\hline 4 & 30 & 70 & --- & 15 & 23.8 \\
\hline 5 & 30 & 70 & --- & 20 & 25.8 \\
\hline \multirow[t]{2}{*}{6} & 30 & 70 & --- & 30 & 29.3 \\
\hline & \multicolumn{3}{|c|}{ Composition of batch No. 3} & & \\
\hline No. & Yellow clay, \% & Grey clay, \% & Argillite, $\%$ & SS, \% & W, \% \\
\hline 1 & 30 & 70 & 1 & 1 & 19.3 \\
\hline 2 & 30 & 70 & 2 & 2 & 20.2 \\
\hline 3 & 30 & 70 & 3 & 3 & 20.3 \\
\hline 4 & 30 & 70 & 4 & 4 & 21.0 \\
\hline 5 & 30 & 70 & 5 & 5 & 21.8 \\
\hline
\end{tabular}

Table 6. Porosity and density of laboratory samples

\begin{tabular}{|c|c|c|c|c|}
\hline No. & SS, \% & Porosity, $\%$ & $\begin{array}{c}\text { Density, kg/ } \\
\mathrm{m}^{3}\end{array}$ & $\begin{array}{c}\text { Compressive } \\
\text { strength, kgf/ } \\
\mathrm{m}^{3}\end{array}$ \\
\hline 1 & 1 & 8.00 & 1650 & 125.9 \\
\hline 2 & 2 & 8.10 & 1632 & 125.6 \\
\hline 3 & 3 & 8.13 & 1609 & 125.5 \\
\hline 4 & 4 & 8.22 & 1595 & 125.3 \\
\hline 5 & 5 & 8.30 & 1570 & 125.0 \\
\hline
\end{tabular}

The comparative analysis of brick samples showed that with the introduction of SS modifying additive into the ceramic mixture, the values of all indicators improved in comparison with the parameters of bricks, produced according to the process regulations of the Ivano-Frankivsk enterprise OJSC "Budivelni Materialy". At the same time, the porosity of solid bricks increased by $4 \%$, the density decreased by $5.0 \%$, the thermal conductivity decreased by $3.2 \%$, and the brick strength remained unchanged, which opens the prospects of their wide use in the construction industry.
Table 7. The comparative analysis of brick samples

\begin{tabular}{|c|l|c|c|}
\hline No. & \multicolumn{1}{|c|}{ Indicators } & $\begin{array}{c}\text { Standard } \\
\text { samples }\end{array}$ & $\begin{array}{c}\text { Samples with } \\
\text { the addition of } \\
5 \% \text { of SS }\end{array}$ \\
\hline 1 & Porosity, $\%$ & 8.00 & 8.30 \\
\hline 2 & Density, $\mathrm{kg} / \mathrm{m}^{3}$ & 1650 & 1570 \\
\hline 3 & $\begin{array}{l}\text { Thermal conductivity, } \\
\text { W/mK }\end{array}$ & 0.62 & 0.60 \\
\hline 4 & Strength grade & 125 & 125 \\
\hline
\end{tabular}

\section{CONCLUSIONS}

1. The possibility of using zeolite from the Sokyrnytsia deposit in purifying wastewater, emitted from utility companies, from the cupric and manganese ions was established.

2. It was found out that at low initial concentrations of heavy metals $\left(0.05-0.1 \mathrm{mg} / \mathrm{dm}^{3}\right)$ zeolite completely adsorbs the cupric and manganese ions within 48 hours, regardless of the size of sorbent grains. Its adsorption efficiency decreases as the concentration of ions in the solution increases. 
3. It was experimentally established that the efficiency of zeolite adsorption for the cupric ions is significantly higher than for the manganese ions.

4. It was found that the adsorption capacity of zeolite is higher than the adsorption capacity of anthracite; thus, using zeolite in the technologies of sewage purification from heavy metals can be recommended.

5. The modifying additive was obtained by means of SS thermal pyrolysis at the temperatures of $600-700^{\circ} \mathrm{C}$. The addition of the modifying additive in the amount of $5.0 \%$ of brick mass into the ceramic mixture can increase its porosity, reduce its density and decrease the thermal conductivity of course solid bricks.

6. The use of technogenic raw materials in brick manufacturing can help to utilize sewage sludge, solve the environmental pollutionrelated problems and extend the raw material base for ceramic materials.

\section{REFERENCES}

1. Abdrakhimov, V.Z., Abdrakhimova, Ye.S. Ceramic composition for manufacturing lightweight bricks. Patent RU 2481303. MPK S 04 V 33/132. Patent search, 2012, http://www.findpatent.ru/ patent/248/2481303.html.

2. Adamenko Ya.O., Arkhypova L.M., Mandryk O.M. 2016. Territorial norm of quality of hydro ecosystems of protected territories. Hydrobiological Journal. English version published by Begell House, http://www.hydrobiolog.narod.ru/

3. Bień, J., Sanytsky, M., Rećko, K., Khrunyk, S. 2007. Energetyczne wykorzystanie odpadów w przemyśle cementowym. Budownictwo o zoptymalizowanym potencjale energetycznym. Praca zbiorowa. T. Bobko, Częstochowa (Poland), 2007, 11-16.

4. Breus, R.V. et al. 2007. Reduction of the accumulated wastes from water purification - sewage sludge by means of their utilization in asphalt concrete. Extended abstract of candidate's thesis. Ukrainian Scientific and Research Institute of Ecological Problems. Kharkiv, 20.

5. De Clippeleir H et al. 2011. OLAND is feasible to treat sewage-like nitrogen concentrations at low hydraulic residence time. Appl Microbiol Biotechnol. 90(4), 1537-1545.

6. Girol, N.N., Boychuk, S.D., Myakishev, V.A. 2006. Process development of ceramic gravel manufacturing from industrial wastewater sludge from water purification plant for its utilization.
Construction and industrial safety. Simferopol, 15-16, 143-147.

7. Gregg, S.J., Sing, K.S.W. 1984. Adsorbtsiia, udelnaia poverkhnost, poristost [Adsorption, surface area and porosity] (Trans.). Moscow: Mir, 306.

8. Malovanyy A. et al. 2014. Combination of ion exchange and partial nitritation / Anammox process for ammonium removal from mainstream municipal wastewater. Water Science \& Technology. 70, 1, 144-151.

9. Malyovanyy M. et al. 2013. Water sorption purification from ammonium pollution. Chemistry \& chemical technology. 7(3), 355-358.

10. Malovanyy M. et al. 2016. Comparative Analysis of the Effectiveness of Regulation of Aeration Depending on the Quantitative Characteristics of Treated Sewage Water. Journal of Chemistry, 9 p.

11. Mandryk O.M., Arkhypova L.M., Pobigun O.V., Maniuk O.R. 2016. Renewable energy sources for sustainable tourism in the Carpathian region. IOP Publishing. IOP Conf. Series: Materials Science and Engineering 144 (2016) 012007. International Conference on Innovative Ideas in Science (IIS2015) 12-13 Nov. 2015, Baia Mare, Romania. Vol. 144, Aug. 2016, http://iopscience. iop.org/issue/1757-899X/144/1.

12. Melnyk L. et al. 2015. Adsorption of Heavy Metals Ions from Liquid Media by Palygorskite. Chemistry \& Chemical Technology. 9(4). 467-470.

13. Ministry of Ecology and Natural Resources of Ukraine 2016. National report on the state of environment in Ukraine in 2014. Kyiv, 254.

14. Ministry of Ecology and Natural Resources of Ukraine 2017. National report on the state of environment in Ukraine in 2015. Kyiv: TOV “Tsentr", 415.

15. Nekrasov, B.V. et al. 1973. Fundamentals of general chemistry. Vol. 2. M: Khimia, 668.

16. Scott, M., Kathleen, A., Prabir, K. 2003. Handbook of zeolite science and technology. CRC Press, 1184.

17. Tulaydan Yu. et al. 2017. Treatment of highstrength wastewater from ammonium and phosphate ions with the obtaining of struvite. Chemistry \& Chemical Technology, 11(4), 463-468.

18. Van Kempen R. et al. 2005. SHARON process evaluated for improved wastewater treatment plant nitrogen effluent quality. Water Sci. Technol., 52, 55-62.

19. Vasylechko V.O., Gryshchouk G.V., Lebedynets L.O., Kuz'ma Yu.B., Vasylechko L.O., Zakordonskiy V.P. 1999. Adsorption of Copper on Transcarpathian Clinoptilolite. Adsorption Science \& Technology, 17 (2), 125-134. 